\title{
"UMBIESS": Innovations Drinks Product of Umbi As Community Empowerment Efforts in Gunungpati, Semarang City for Sustainable Development Goals (SDGs)
}

\section{Hafidzoh Najwati, Laelatul Hikmah, and Budiyono}

Department of Public Health, University of Diponegoro, Semarang, Indonesia

\section{Abstract}

Indonesia is the third largest producer of sweet potato in the world. Most of the people in Gunungpati, Semarang city, are farmers, but the processed agricultural products of sweet potato have not to use optimally. The purpose of this program is to empower the community in the management potential of sweet potato so that it can increase the sale value of sweet potato, accelerating diversification, and can compete in international markets - empowerment program of UMBIESS production using

Corresponding Author: Hafidzoh Najwati hafidzoh.najwati@gmail.com

Received: 26 December 2018 Accepted: 23 February 2019 Published: 7 March 2019

Publishing services provided by Knowledge E

(c) Hafidzoh Najwat et al. This article is distributed under the terms of the Creative Commons Attribution License, which permits unrestricted use and redistribution provided that the original author and source are credited.

Selection and Peer-review under the responsibility of the 2 nd International Meeting of Public Health 2016 Conference Committee. method Sociopreneurship approach that is Focus Group Discussion(FGD); Production Practice (UMBIESS production and certification of products, packaging, and labeling, the establishment of SMEs); Cooperation Partnership; Training and Monitoring; and Evaluation of Sociopreneurship Effectiveness. The result of this program is the creation of UMBIESS products that have certified nationally; as a pioneering pilot SMEs, which groups of women farmers "Karya Mandiri UMBIESS"; and already have a marketing partner for UMBIESS products to the public. Besides empowerment is expected to improve the economy of the village society Gunungpati to exploit the potential of the local area. UMBIESS product can be used as a community empowerment program that creates new jobs, reducing poverty and enhancing food security sweet potato. So that is contributing to the achievement of Sustainable Development Goals (SDGs).

Keywords: Sweet potato; UMBIESS; ecopreneurship;, community empowerment

\section{Introduction}

The head of state and inter-government in September 2015 agreed to set the world on a path towards sustainable development through the adoption of the 2030 agenda for sustainable development. This agenda includes 17 sustainable development goals, or SDGs, the which sets out quantitative objectives across the social, economic, and environmental dimensions of sustainable development all to achieved by 2030 (The United Nations 2015). The second goal has a series of targets to support the three interrelated components of the goal: ending hunger, achieving food security and improved nutrition, 
and promoting sustainable agriculture. Making the second goal is complicated as it couples natural processes with social and economic processes. Most targets concern the promotion of sustainable agriculture; this creates an imbalance and an additional objective proposed for nutrition. There is consensus on essential food security and nutrition indicators, but trade-offs with the environmentally focused goals make signs for sustainable agriculture more complex (Maryet al. 2015).

Indonesia is the third largest country in the world in producing a sweet potato. Sweet potato (Ipomoea batatas $L$ ) is cultivated as a perennial in tropical and subtropical lowland agro-ecologies, although it is well adapted to other zones and can grow over widely different environments (Agriculture, Forestry, and Fisheries 2011). According to the Food and Agriculture Organization (FAO) increase in productivity in 2020 to $0.61 \%$ of land area is $1.93 \%$ annually. Nutritional content of sweet potato is the most complete than vegetables (Anjak 2010). Sweet potato contains Vitamin A, Vitamin C, ascorbic acid, Tianjin, riboflavin, niacin, phosphorus, iron, and calcium. In addition to the content of vitamins and minerals, the levels of carotenoids in sweet potato as the main ingredient similar to the formation of vitamin A carotene in carrots (Nani \& Yati 2013). In addition to nutritional completeness, some purple sweet potato contain anthocyanins which have a physiological function as cancer prevention, protection from bacterial, protection from liver damage, heart and stroke disease, as well as playing an important role in reflecting and repair of DNA, which can optimize the function of the body's cells (Rosidah 2010).

Sweet potato in Indonesia has potential as planned development of industrial raw materials, both for food and nonfood items. However, the sweet potato in Indonesia has not been regarded as an essential commodity and not optimal in its use. One of the areas that have the potential Semarang agricultural sector is quite large, and contribute significantly to efforts to achieve food security in the city of Semarang, which is in Gunungpati districts (Maria \& Dicky 2012). The total area of $54.11 \mathrm{~km}^{2}$, most of the territory consists of rice fields and plantations. Based on data from National Statistics Agency (BPS) Semarang in 2015, Gunungpati districts are the third-ranked as a most significant producer of sweet potato in Semarang, with a period of production by 23 ton (Dinas Pertanian Kota Semarang 2014).

The level of education and skills of the farmer in Gunungpati is limited or relatively more low so that they can not access to formal employment (Nurma \& Iwan 2013). Residents mostly worked as a farmer; it is as much as 5.534 residents (BPS2015). However, processing of agricultural products from sweet potato untapped into high-value products or not used optimally. The sweet potato products are still minimal. Food self-sufficiency and food processing alternatives currently intensified by Semarang (Puji 2014). 


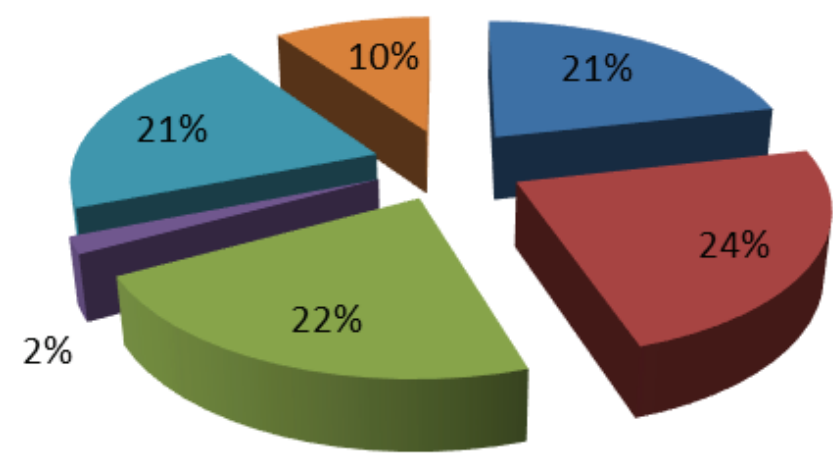

Gunungpati

- Mijen

Ngaliyan

Tembalang

- Semarang Utara

Banyumanik

Figure 1: Percentage of commodity production of sweet potato in Semarang 2003 (Source: Constituents analysis (2009)).

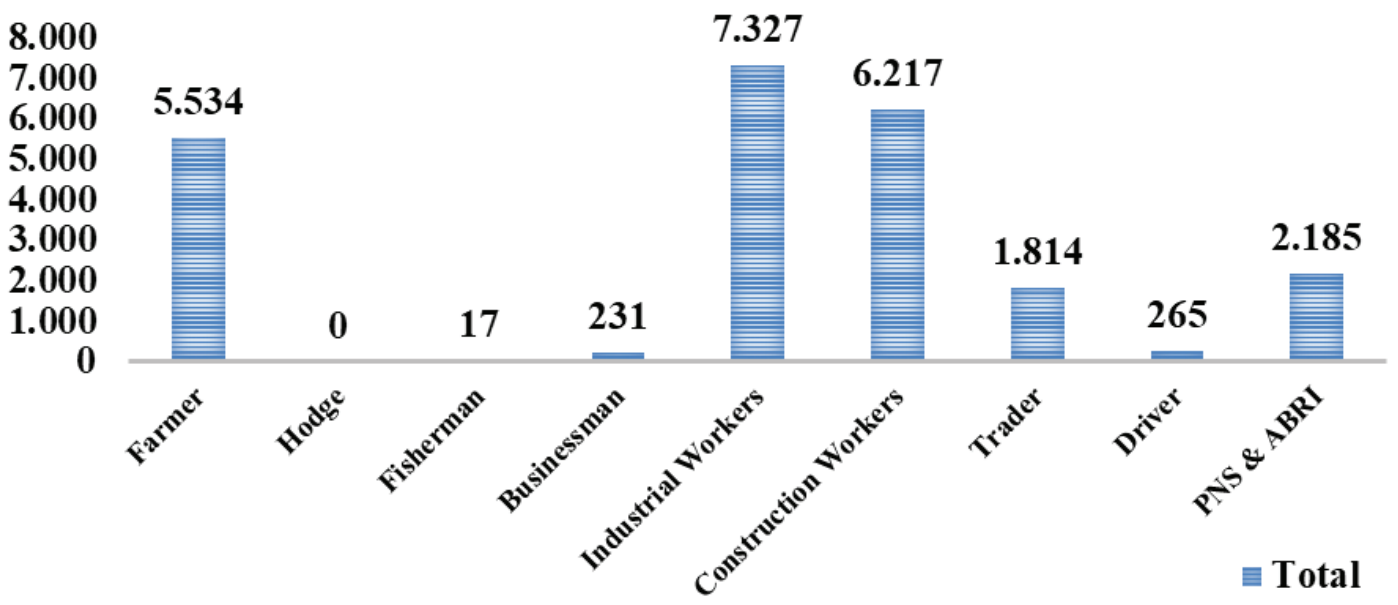

Figure 2: The Livelihoods of Residents Gunungpati Districts in 2015.

Indonesian society is more interested in the beverage packaging, one of them is a soft drink, but it is most contain preservatives and sweeteners are not natural. Consumption of soft drinks plays a significant role in a variety of diseases like obesity, diabetes, dental and bone disorders, and others, more so among children and adolescents. The toxic effects of soft drinks have gained much attention, due to the frequent scientific reports and media attention (Xavier et al.2007). Therefore, empowerment by creating drink products innovation UMBIESS (Drink Sari Umbi) contains nutrients for a healthy body. The purpose of this program is to increase the sale of sweet potato, accelerating diversification with optimize the use of local food sources available, and can be exported to various countries, so that UMBIESS have high competitiveness in the international market. UMBIESS product is one of the community empowerment programs that create 
self-reliance efforts to alleviate poverty and strengthen food security of sweet potato, thus contributing to the Sustainable Development Goals (SDGs).

\section{Methods}

Community empowerment program UMBIESS production conducted in Gunungpati, Semarang. To facilitate the people in producing and marketing products UMBIESS formed the pioneer of SMEs, namely the Group of Women Farmers (GWF) "Karya Mandiri UMBIESS." Social entrepreneurship (ecopreneurship) is the field in which entrepreneurs tailor their activities to directly tied with the ultimate goal of creating social value (Samer 2012). A method used in this Community Empowerment Program is ecopreneurship method, namely by performing entrepreneurial UMBIESS production based on social issues would be the lack of innovation in the use of agricultural products sweet potato into a product that has a higher sale value. The steps committed in ecopreneurship method can be shown in the chart as follows:

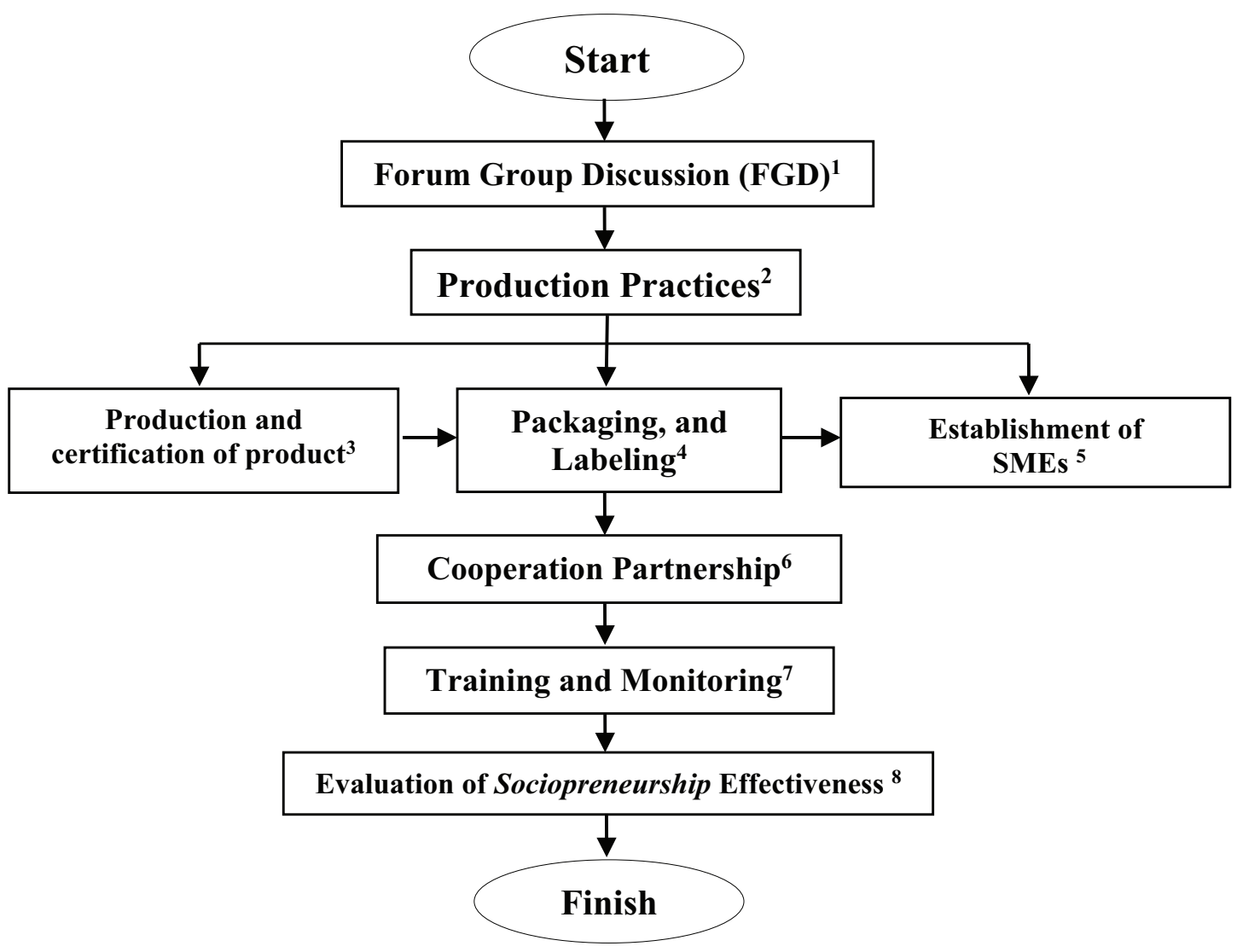

Figure 3: Sociopreneurship Methods of Community Empowerment Program UMBIESS Production. 


\subsection{Forum group discussion (FGD)}

Through the activities of the Forum Group Discussion (FGD) conducted public education activities related to the potential goal sweet potato as raw material for the food industry viewed from resources; the flexibility of the article; the people acceptance; nutrient content; and business potential. At this untapped stage also socialize potential sweet potato agricultural output that is around Gunungpati, to use as an innovative product that is UMBIESS (Drinks Sari Umbi). Communities also explained the purpose and benefit UMBIESS, how to manufacture, marketing methods, and financial arrangements. In addition to socialization, at this stage of discussions with the community about the formation of the organization Group of Woman Farmers (GWF) "Karya Mandiri UMBIESS," so that the establishment of the agreement and support of the community to the community empowerment program.

\subsection{Production practices}

This stage is the most critical part of this empowerment program, started from produce UMBIESS up with the establishment of Micro, Small and Medium Enterprises (SMEs) which can explain as follows:

\subsubsection{Production and certification of product}

At this stage, prepared tools and sweet potato raw materials used for production UMBIESS on a small scale to large scale. While the step of manufacture includes: the manufacture of the starting material (cutting and cooking), and the manufacture of Drink Sari Umbi (drink sari umbi filtration, sterilization, the appropriate dose measurement, and other materials to the mixing formulas become a product). UMBIESS production process using the best quality of sweet potato that has been through the treatment process are sterile and sanitary, and targets in this stage obtained product certification from a national accreditation committee, such as the P-IRT, BPOM, and Halal MUI.

\subsubsection{Packaging and labeling}

At this stage, the product UMBIESS ready to put into the packaging and labeled as an appeal to marketing. Packaging products accompanied by a variety of health information related to a wide range of sweet potato and its benefits to health, to educate the public. 


\subsubsection{Establishment of SMEs (Small and Medium Enterprises)}

At this stage, cooperation with the local government to carry out the registration of SMEs in Semarang City Cooperative Office. Establishment of Small and Medium Enterprises (SMES) UMBIESS, by providing a semi-permanent place to sell UMBIESS step is to gather the community to become a member of this program.

\subsection{Cooperation partnership}

Through the establishment of SMEs, conducted sales and marketing strategy UMBIESS products, such as marketing director and through partners. Direct marketing was done by the sales Cash On Delivery (COD) to the consumers by the public. While sales through partners made with an agreement for the purchase of products UMBIESS. The partners are shops, food stalls to school canteens that are around Gunungpati. Sales also performed with the center offering souvenirs in the city of Semarang and other broader marketing.

\subsection{Training and monitoring}

At this stage of the instruction given to the Group of Women Farmers (GWF) "Karya Mandiri UMBIESS" conducted regularly scheduled every month. It expects from the training provided to improve the ability of farmers in producing quality UMBIESS. Training gives in the form of how to manage agricultural land sweet potato, manufacture UMBIESS production, production, and marketing training. By using model "learning by doing" the farmers can absorb knowledge and knowledge optimally. At this stage also be monitored from planting a sweet potato, land management, production phase, up to the marketing stage, this monitoring aims to ensure that all stages of the planned program can run effectively. Constraints encountered in the field that can be quickly resolved so that the expected results will be optimal.

\subsection{Evaluation of sociopreneurship effectiveness}

At this stage, the evaluation of the results of the implementation of the program UMBIESS production, regarding qualitative (innovations produced and developed the product) and quantitative (amount of products produced in a certain time interval). Sociopreneurship evaluation can be measured by the achievement of an increase in production capability 
UMBIESS, ensuring the sustainability program, and reduced the problems faced by the community.

\section{Results}

Community Empowerment Program implementation results are as follows :

1. The organizational structure of the Group of Women Farmers (GWF) "Karya Mandiri UMBIESS."

\section{UMBIESS product and certification}

\section{SMEs and Cooperation Partnership widely}

The organizational structure of production UMBIESS, called Group of Women Farmers (GWF) "Karya Mandiri UMBIESS." This organization serves to manage business group UMBIEES be able to develop and be able to go well so that the production will be more focused. The organizational structure of the Group of Woman Farmers (GWF) "Karya Mandiri UMBIESS" is as follows:

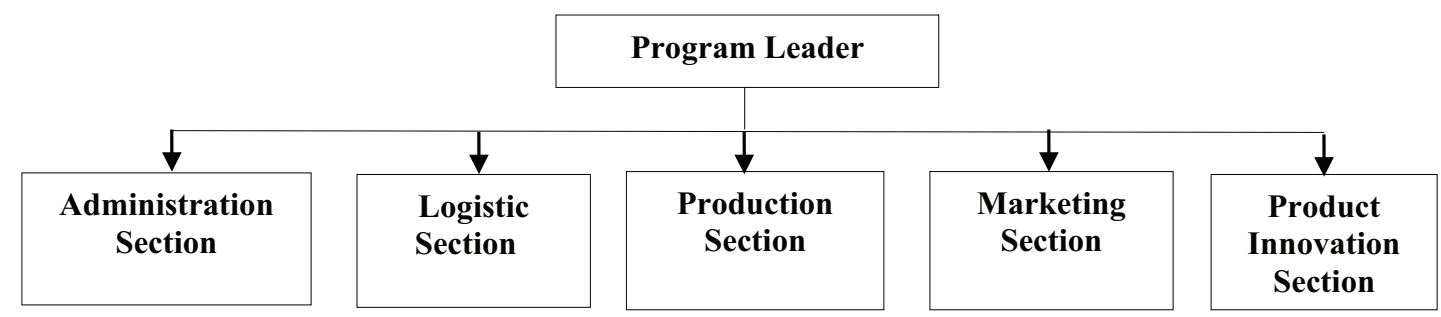

Figure 4: Organizational Structure of the Group of Women Farmers"Karya Mandiri UMBIESS".

The organizational structure of production UMBIESS consists of the farming community, particularly the Group of Women Farmers (GWF). Empowerment to GWF is a strategy to increase productive domestic economy so that the desired business group will be able to develop independently by utilizing local potential which is directly managed by the local community. So if the training program complete is expected communities can continue and expand the program.

Besides the organizational structure, also set up a schedule for mentoring activities for Community Empowerment Program UMBIESS production. The following is a schedule of mentoring:

In the process of this assistance has also been analyzed Cost of Production (CoP) Product UMBIESS to specify sales price. Determination of Cost of Production and Price Sales made by the community. While the advantages of this UMBIESS product sales will 
TABLE 1: Schedule Community Empowerment of UMBIESS Production.

\begin{tabular}{l|l|l|} 
No & Meeting & Activity \\
1 & Meeting 1 & Forum Group Discussion (FGD) \\
2 & Meeting 2 & 1st Mentoring \\
3 & Meeting 3 & 2nd Mentoring \\
4 & Meeting 4 & 3rd Mentoring \\
5 & Meeting 5 & Small Scale Production and Marketing \\
6 & Meeting 6 & Monitoring dan Evaluation \\
7 & Meeting 7 & Establishment of SME and Cooperation Partners \\
8 & Meeting 8 & Large Scale Production and Marketing \\
9 & Meeting 9 & Monitoring dan Evaluation \\
10 & Meeting 10 & Production and Expanded Marketing \\
11 & Meeting 11 & Evaluation
\end{tabular}

be entered into by the group. Here is the Cost of Production (CoP) UMBIESS identified by the communities.

TABLE 2: Cost of Production (CoP) for UMBIESS product.

\begin{tabular}{l|l|l} 
No & Material(s) & Price \\
\hline 1 & Sugar & IDR 2.000 \\
\hline 2 & Chocolate or Vanilla flavor & IDR 1.500 \\
\hline 3 & Bottle & IDR 1.000 \\
\hline 4 & Sticker & IDR 500 \\
\hline 5 & Sweet Potato & IDR 0 (free cost from the \\
& & community) \\
\hline TOTAL & IDR 5.000
\end{tabular}

After knowing Cost of Production (CoP) manufacture the product, then the pricing of product as follows:

1. Cost of Production (CoP) $=$ IDR 5.000, -

2. Basic Selling Price $=$ IDR 5.000, -

3. Retail Price $=$ IDR 6.000,-

The results of the event are the product UMBIESS with basic raw materials of various kinds of sweet potato (white sweet potato, sweet potato yellow, red sweet potato, and sweet potato purple) combined with a variety of flavors are popular with the public (original, vanilla, chocolate) and natural sweetener. UMBIESS products hygienically packed in $250 \mathrm{ml}$ bottles of practical size. Attractive packaging used in UMBIESS equipped with all kinds of information related to sweet potato for health benefits, as the intellectual effort (health education) to the public. 

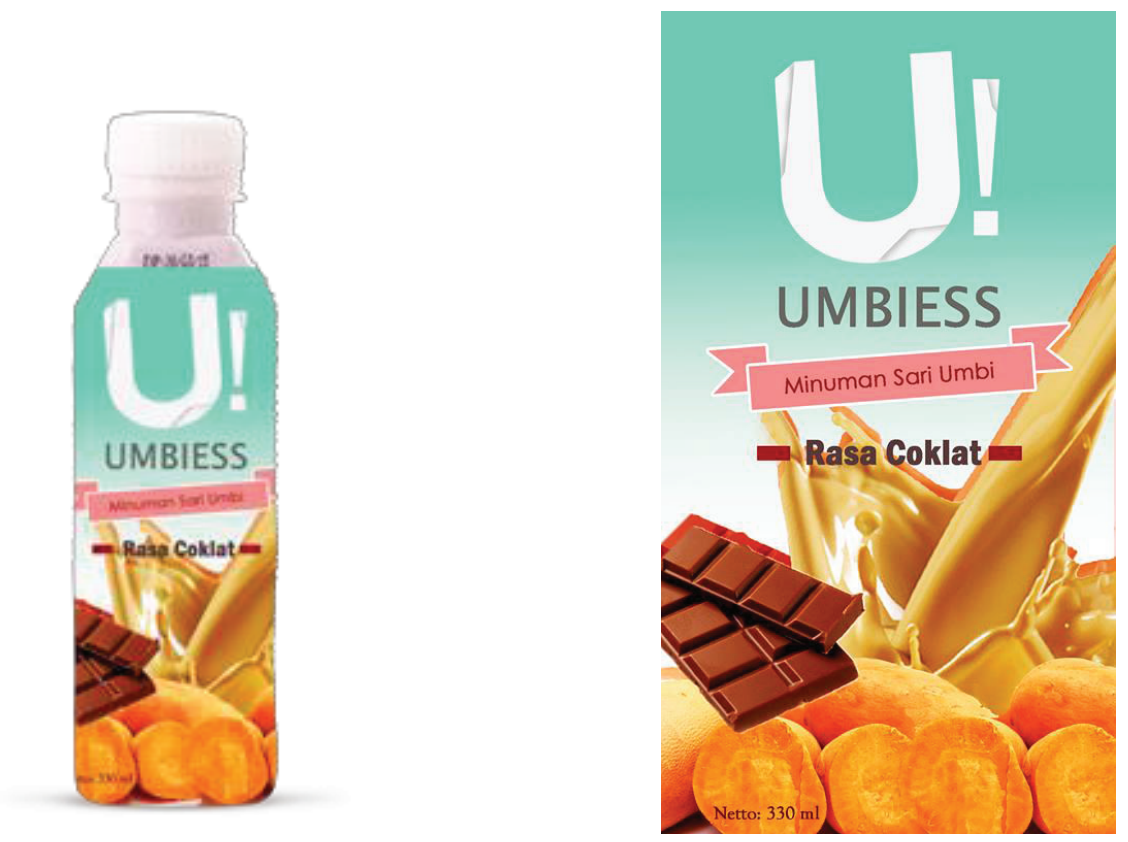

Figure 5: Bottles of UMBIESS Products.

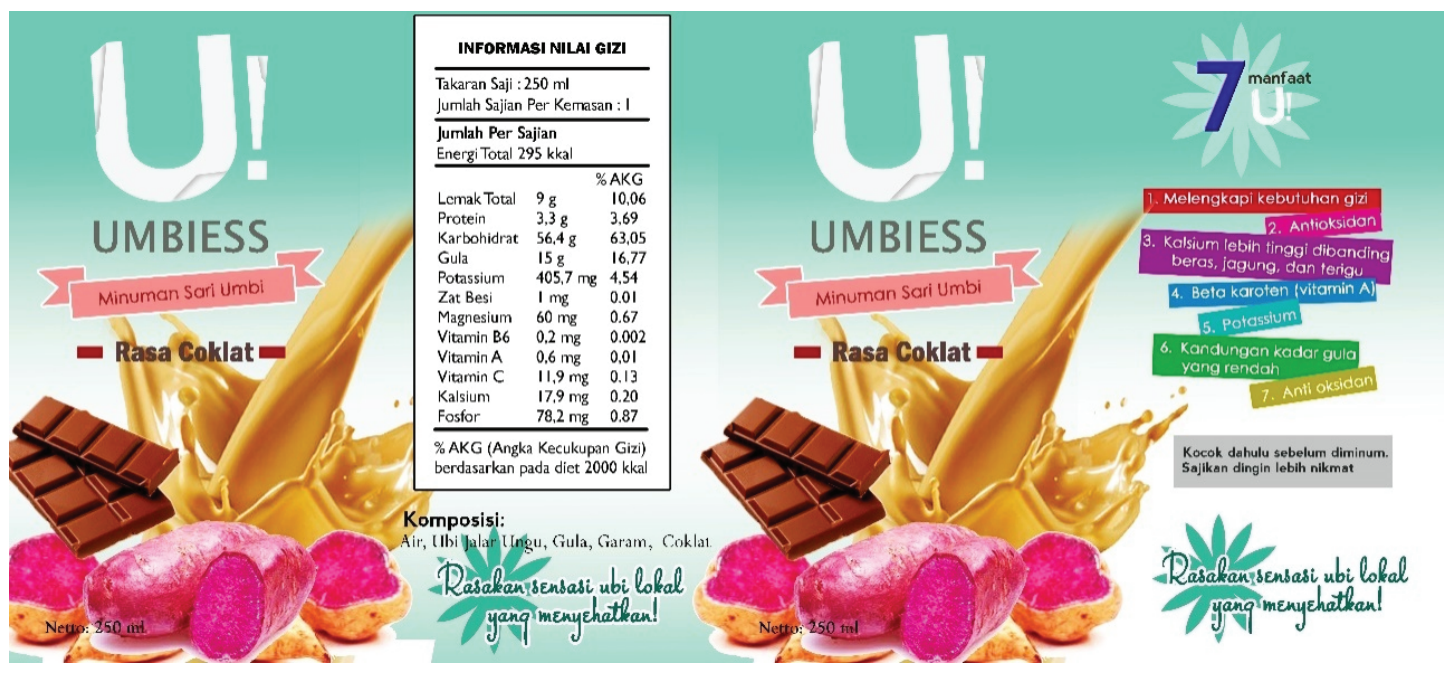

Figure 6: Packaging Design of UMBIESS products for Health Education.

Not only from the process of production and marketing, but the making of UMBIESS also performed arrangements trademarks and certification PIRT, BPOM, and Halal MUI, so UMBIESS product has been proven safe for consumption.

\section{Discussion}

The potential of sweet potato as the raw materials industry of food in Indonesia is still huge, the cultivation of sweet potato is smooth and the harvest period is short, causing material resources abundantly available, besides sweet potato also have high flexibility 
in processing, its nutritional content is complete even some of them are very important substance for the body as physiological function is anthocyanin and Carotene as antioxidants and fiber prebiotic rapinasa functioning. Another potential of sweet potato is the people acceptance of the product from sweet potato to be appreciated by the public as necessary materials well known in the community.

With the potential of sweet potato in Indonesia, the product innovation drinks UMBIESS can be used as one of the Program for Community Empowerment to increase the sale value sweet potato, accelerating diversification, strengthen food security yams, create self-sufficiency efforts to alleviate poverty, and potentially exported to many countries in the international market. So that the product UMBIESS can contribute to the achievement of Sustainable Development Goals (SDG's).

\section{Conclusions}

Through this community empowerment program Gunungpati, Semarang can increase economic capabilities independently with exploiting the potential of existing local products. UMBIESS beverage product innovation can be used as one of the leading Indonesian products to be exported to various countries so that the product UMBIESS have high competitiveness in the market international to support Sustainable Development Goals (SDGs).

\section{Acknowledgments}

Thanks to the Diponegoro University and the Faculty of Public Health that has helped the research of this program, thanks to Mr. Budiyono, SKM.M, Kes as supervisor; Dawn Bintari Fajar Kurnianingtyas, Diah Palupi Nur Indarti, as well as Auliya Rahmawati as a team member; thank all the friends Diponegoro University who participated in the making of this paper, as well as to thanks the committee that has held The $2^{\text {nd }}$ International Meeting of Public Health (IMOPH), 2016.

\section{References}

[1] Agriculture, Forestry, and Fisheries. 2011. Sweet potato (Ipomoea batatas L.) production. DepartmentAgriculture, Forestry and FisheriesRepublic of South Africa http://www.daff.gov.za/docs/Brochures/PG_SweetPotato.pdf(accessed December 27, 2016). 
[2] Anjak.2010. Prospek Pengembangan Ubi Jalar Mendukung Diversifikasi Pangan dan Ketahanan Pangan. http://pse.litbang.pertanian.go.id/ind/pdffiles/ anjak_2010_10.pdf (accessed October 19,2016)

[3] BPS (National Statistics Agency).2015. Jumlah Penduduk berdasarkan Mata Pencaharian di Kota Semarang, 2012 - 2015 https://semarangkota.bps.go.id/ linkTableDinamis/view/id/10 (accessed December 27,2016).

[4] Dinas Pertanian Kota Semarang. 2014. Pertanian Dalam Angka 2013.Semarang: Dinas Pertanian Kota Semarang.

[5] Maria, Sudarwani., and Dicky Ekaputra. 2012. Optimalisasi Lahan Pertanian Produktif dalam Rangka Pengentasan Kemiskinan di Kecamatan Gunungpati Kota Semarang. Laporan Penelitian.Lembaga Penelitian dan Pengabdian Masyarakat. Universitas Pandanaran Semarang. http://repository.unpand.ac.id/ download.php?file=20160618-Optimalisasi\%20Lahan\%20Pertanian\%20Produktif\% 20Dalam\%20Rangka\%20Pengentasan\%20Kemiskinan\%20di\%20Kecamatan\% 20Gunungpati\%20Kota\%20Semarang.pdf (accessed December 27,2016).

[6] Mary, Scholes, et al.2015. Review of the Sustainable Development Goals: The Science Perspective. Paris: International Council for Science (ICSU).ISBN: 9780-930357-97-9. http://www.icsu.org/publications/reports-and-reviews/review-oftargets-for-the-sustainable-development-goals-the-science-perspective-2015/ SDG-Report.pdf (accessed December 27, 2016).

[7] Nani, Zuraldaand Yati Suprapti. 2013. "Usaha Tani Ubi Jalar sebagai Bahan Pangan Alternatif dan Diversifikasi Sumber Karbohidrat."Bulletin AgroBio 4 (1) : 13-23. http: //biogen.litbang.pertanian.go.id/terbitan/pdf/agrobio_4_1_13-23.pdf

[8] Nurma, Kumala., and Iwan Rudiarto. 2013. "Identifikasi Alih Fungsi Lahan Pertaniandan Kondisi Sosial Ekonomi Masyarakat Daerah Pinggiran di Kecamatan Gunungpati Kota Semarang." Jurnal Wilayah Dan Lingkungan. Volume 1 Nomor 2, Agustus 2013, 175-188 http://ejournal2.undip.ac.id/index.php/jwl/article/viewFile/133/pdf.

[9] Puji, Utami.2014. Berharap Sejahtera dari Ketela. http://regional.kompas.com/read/ 2014/10/29/14043261/Berharap.Sejahtera.dari.Ketela. (accessed October 19,2016).

[10] Samer, Abu-Saifan. 2012."Social Entrepreneurship:Definition and Boundaries."Technology Innovation Management ReviewFebruary 2012. http: //timreview.ca/sites/default/files/article_PDF/Saifan_TIMReview_February2012_0. pdf (accessed December 27,2016).

[11] Rosidah.2010. Potensi Ubi jalar sebagai Bahan Baku industry pagan. TEKNUBUNGA Volume 2 No.2-April. http://journal.unnes.ac.id/nju/index.php/teknobuga/article/ viewFile/1179/1116 
[12] The United Nations.2015. Transforming Our World: The 2030 Agenda for Sustainable Development. https://sustainabledevelopment.un.org/post2015/ transformingourworld (accessed December 27,2016).

[13] Xavier.R, et al. 2007. "Soft drinks and hard facts: a health perspective." ASEAN Food Journal 14 (2): 69-81

[14] http://www.ifrj.upm.edu.my/afjv14(2)2007/69-81.pdf 